\title{
YKL-40 Protein Measurement
}

National Cancer Institute

\section{Source}

National Cancer Institute. YKL-40 Protein Measurement. NCI Thesaurus. Code C142294.

The determination of the amount of YKL-40 protein present in a sample. 